NBER WORKING PAPER SERIES

\title{
ISSUES IN THE DESIGN OF SAVING \\ AND INVESTMENT INCENTIVES
}

David F. Bradford

Working Paper No. 637

\author{
NATIONAL BUREAU OF ECONOMIC RESEARCH \\ 1050 Massachusetts Avenue \\ Cambridge MA 02138 \\ February 1981
}

\begin{abstract}
This author is Professor of Economics and Public Affairs Princeton University. This paper was prepared for presentation at the Urban Institute Conference on Depreciation Measurement and Policy, Washington, DC, December 1, 1980, while the author was a visitor at the Industrial Institute for Economic and Social Research, Stockholm, Sweden. The research reported here is part of the NBER's research program in Taxation and project in Capital Formation. Any opinions expressed are those of the author and not those of the National Bureau of Economic Research.
\end{abstract}


Issues in the Design of Saving and Investment Incentives

\section{ABSTRACT}

This paper examines the characteristics of and interactions among measures to effect saving and investment incentives ("S-I incentives") in the context of an income tax system that is inadequately indexed for inflation. Examples are proposals for more rapid depreciation of buildings and equipment and proposals to exempt larger amounts of interest income. S-I incentives are classified into "consumption tax" and "direct grant" types, and it is shown that these differ in their influence on portfolio choices, in their sensitivity to inflation and in the design problems they present. Stress is placed on requirements for neutrality with respect to asset durability and portfolio composition. A new result is the derivation of the reduction in interest taxation yielding neutrality in the presence of partial expensing of real investment or equivalent investment incentive.

Professor David F. Bradford Woodrow Wilson School Princeton Iniversity Princeton, New Jersey 08544 (609) $452-4842$ 
ISSUES IN THE DESIGN OF SAVING AND INVESTMENT INCENTIVES

David F. Bradford

The view is widespread that the rate of accumulation of capital in recent years in the United States has been too low. This conclusion is based in part upon a comparison of the rate of net investment, especially of business fixed investment, relative to aggregate output both with its past value in the U.S. and with its value in the other advanced industrial countries. It is based as well upon symptoms that are presumptively traceable to a slow-down in capital formation, most especially the apparent cessation in the growth of labor productivity.

A deterioration in the rate of return to savers resulting from the interaction of inflation with an unindexed tax system is often cited among the reasons for this shift in performance of the U.S. econorny. In particular, the failure of the tax rules to permit correct accounting for depreciation and capital gains, together with a not obviously explicable reluctance of businesses to use the LIFO inventory procedures permitted under the tax law, result in a burden of tax on the return from investment that increases with the rate of inflation. Furthermore, because the tax treatment of nominally demoninated assets also ignores inflation, considerable if poorly understood stress is placed upon the financial structure of the economy in a period of rapid increase in the price level. 
A consequence of this view, that there is a problem, and that taxes have something to do with it, has been a movement to increase the incentive to save and invest by changing the rules. Somewhat oddly, there seems to be relatively little interest in approaching this by asking what steps would be necessary to correct for inflation. Nor has there yet appeared an explicit strategy of shifting taxation away from an income and towards a consumption base, a policy not necessarily related to inflation. Perhaps because of the perceived complexity of the former and unfamiliarity with the latter, policy-makers and the interest groups actively involved with the issue have been attracted to ad hoc measures.

Most prominent and widely discussed among these have been proposals to allow taxpayers to write off the cost of acquisition of productive assets, for purposes of calculating income subject to tax, more rapidly than the economic definition of income would imply. Bills sponsored by House Ways and Means Committee members Conable and Jones (the "10-5-3 proposal"), by Committee chairman AI Ullman, and by the Senate Finance Committee (the "2-4-7-10 proposal") would in various ways provide for a grouping of assets into categories, for which relatively rapid write off for tax purposes would be allowed. Other changes in tax rules recently enacted or currently discussed with a similar objective of reducing the tax on capital income from present inflation-influenced levels are lower effective rates on long-term capital gains, exemption of a limited amount of dividends and savings account interest from individual income taxation, and relaxation of restrictions on tax deferred saving of the sort now allowed via employer sponsored pension programs, Individual Retirement Accounts and Keogh Plans. 
These phenomena and policy choices raise issues of economic analysis, both theoretical and empirical, which have attracted an appropriate amount of professional attention. Perhaps the most important are whether the facts indeed warrant the conclusion that there should be more capital formation and whether, if so, rule changes of the sort under consideration are likely to call it forth. This paper dodges those difficult questions. It considers rather the problem of designing tax and related rules to promote capital formation. 1

To put the matter somewhat more precisely, I take up in this paper the characteristics of and interactions among measures to effect saving and investment incentives (henceforth "S-I incentives") in the context of an income tax system that is inadequately indexed for inflation. Although the issues have been separately addressed many times, a treatment that is at once unified and reasonably simple is lacking.? Furthermore, existing analyses that may incorporate more realistic detail have failed to appreciate sufficiently what legal commentators call the "pressures" introduced to the tax system by inflation and by the present ad hoc measures to deal with it.

These pressures are by and large created by the opportunity to make money by undertaking transactions which have offsetting effects on the balance sheet, but different tax consequences, a process I have referred to as "tax arbitrage." It is these opportunities for arbitrage profit and how the sys-

1 I have addressed these larger issues in Bradford [1980]. Readers may also find helpful the discussion there of the problems created by inconsistent treatment of different forms of savings. For further discussion of the general issues see King [1980]. For empirical analysis of the U.S. experience see, for example, Boskin [1978], Fisner [1977], Feldstein [1977a,b; 1980], Malkiel [1979].

2 For an examination of selected investment incentive proposals under consideration recently in the United States see Hendershott and Hu [1980]. 


\section{$-4-$}

tem eliminates them that I shall stress in the following pages. Underlying the analysis in this paper is the view that rules which do not work well in a simple model world will also not work well in the complex real world. This is the justification for confining attention almost wholly to situations of no uncertainty, no borrowing and lending constraints, and uncomplicated financial relationships. There is no doubt that the extreme sorts of outcomes that emerge in simple models, such as conclusions that a taxpayer's wealth will consist all of one asset, or involve large borrowing, will be often be prevented in actuality by information and other uncertaintyrelated costs. It is clear that a proper treatment of uncertainty is necessary to a full understanding of capital market equilibrium. However, arbitrage among relatively risk-free assets represents a significant subset of the transactions that must be dealt with by the tax system. The qualitative character of outcomes predicted by the certainty models is observed in the real world. Furthermore, the learning process is obviously still incomplete and cheap highspeed information handling is increasingly extending sophisticated tax arbitrage to a wider market. Thus problems now manifested in the "aggressive" behavior of a few taxpayers are quite likely to be seen more generally in the future.

In Section I below, I sketch out the criteria applicable to choice among saving and investment incentives and offer a classification of measures differing according to the transactions to which they apply and the way they work. Section II looks at the major elements of this structure in the context of stable prices, while section III takes up the difficult problems posed by inflation. There is a brief summing up in Section IV. 
I. BACKGROUND ON SAVING AND INVESTMENT INCENTIVES

Some preliminaries: First, as to what I mean by saving and investment. I shall use the terms more or less interchangeably, but to the extent there is a distinction, investment refers to the acquisition of a real asset, while saving refers to the foregoing of consumption. Second, as to what I mean by saving and investment incentives. The background for this discussion is an income tax system. An income tax, by definition, embodies a saving or investment disincentive in that it creates a divergence between the rate of return on investment and the yield to the saver. Inflation may increase this tax wedge. Thus the incentives we are considering are relative to existing disincentives, whatever their merits.

It is important to be aware of a resulting ambiguity of the term saving or investment incentive as applied to the measures studied here. As I have stressed elsewhere [1980], in view of the government's budget constraint an incentive such as the investment tax credit may be bought at the price of higher tax rates than would otherwise be possible. The net effect may be an increase in the tax wedge applicable, at least for some savers.

\section{Criteria for Choice Among S-I Incentives}

At the risk of banality, I would suggest that the criteria for choice among S-I incentive measures can be summarized by the familiar trinity of equity, efficiency and simplicity.

Equity. As usual, equity is the most difficult criterion to deal

with. To start with, one of the objectives of currently considered S-I measures is to offset inequities that have been perpetrated by inflation, and thus concentration on the static characteristics of rules may miss part of the point. 
This is a particular aspect of the more general problem of distinguishing between transition and steady-state effects. It is regretable that I shall have most to say about the better-understood steady state properties of S-I incentives. As we shall see, there are essentially two sorts of available S-I incentives. The first -- which I call C-tax measures -- tend to equalize the rate of return received by savers at all levels of economic well-being. The second -- which I call direct grant measures -- tend to raise all rates of return received by savers, relative to the social rate of return, but do not alter the differentials among after-tax rates of return on savings characteristic of a graduated income tax. Even with a fixed structure of tax rates the difference in relative individual welfare involved is not a priori certain, as it has to do with the lifetime pattern of earnings and consumption, but it is plausible that the former class of incentives (basically deductions from the income tax base) is relatively more favorable to high bracket taxpayers than the latter (basically investment grants or credits). If desired, such differences could be offset by adjustments in marginal tax rates. This would leave horizontal equity differences between the two approaches, and these are essentially the same as those involved in choosing between a consumption base and and an income base for taxation. Relative to a consumption tax an income tax penalizes those who postpone consumption, whether because they simply prefer to do so, or because their labor earnings, gifts, transfers, etc., occur early in life.l

I For further discussion of this issue see Bradford and Toder [1976]. 
Efficiency. As Auerbach [1979b] has emphasized, we are dealing here with a problem in the economics of the second best. This means that, for example, a measure creating a divergence in the real rates of return on investment in machines of different durability may not be inferior to a measure, similar in most other respects, that causes these rates to be equalized. Our analysis of S-I incentives will simply point out the distortions they engender. There are three margins of trade-off of particular interest. First is that between present and future consumption. An income tax introduces a wedge between the trade-off available to individuals, through borrowing and lending or through real investment and production, and that available socially via the production process--the social rate of return on investment. It thus inherently involves an inefficiency, albeit a potentially second best one, since revenue must be raised somehow. When an income tax is assessed at different rates on different individuals, there is also a violation of exchange efficiency: different individuals have different marginal rates of substitution of present for future consumption. As has been mentioned, S-I incentives of the C-tax type ameliorate both sorts of wedges, while direct grant measures simply shift the distribution of private rates of return, after taxes, upward relative to the social rate of return.

The second margin is between investment in different forms or different sectors. This is a matter of production efficiency. If the real social rate of return is not the same in two activities, an opportunity exists to increase consumption in all periods by shifting resources from the low yield 
to the high yield activity. Such a situation commonly arises under an income tax with the weaknesses typical of actual tax accounting systems. Individuals have an incentive, for example, to push investment in owner occupied housing to the point that the marginal social (and private) return equals the after-tax return in fully taxed industries. Similar inefficiencies are predicted by theory when S-I incentives are limited to particular classes of assets, for example, manufacturing equipment, or to particular industries. A particular case is the difference in social rate of return to capital of different durabilities that is predicted when an investment credit is not appropriately varied with the service life of the asset. At a more refined level of analysis, similar comments would apply to the risk characteristics of real investments.

A third significant margin, between different assets in the household's portfolio, also involves questions of risk bearing. Efficient allocation of risk will normally imply a certain division of each individual's portfolio among real asset types and among financial instruments such as bonds and shares. Equilibrium portfolios with taxes may be expected to diverge from efficiency, and S-I incentives often worsen the distortions characteristic of the existing income tax, typically in the direction of increasing debt-equity ratios in the aggregate and concentrating debt ownership relatively in low tax bracket hands (including life insurance and pension fund portfolios).I The degree to which the S-I incentive displaces the existing income tax presents a further aspect of efficiency. It is reasonable to suppose

1 For analyses stressing this efficiency problem see Gordon [1980] and Gordon and Malkiel [1980]. 
that the basic outlines of the existing tax system will be maintained, with the relatively minor addition of S-I incentive features. It is also the case that the existing system has solved badly many problems of measureing income from capital, notably in the treatment of owner-occupied houses, accruing capital gains, and state and municipal bond interest, and in the absence of inflation adjustments. If the effect of the S-I incentive is to reduce reliance on these aspects of the income tax, it also diminishes the inefficiencies associated with such defects of income measurement.

Simplicity. It is difficult to say very much in general about the potential tendency of S-I incentives to complicate further or to simplify compliance with and enforcement of the tax law. There is a certain risk that S-I incentives will bring with them hard-to-administer rules to prevent "abuse", as in the present rules disallowing deduction of interest traceable to the purchase or holding of tax exempt bonds, or will require inherently complex calculations, as in the case of some aspects of inflation adjustment.

One desirable characteristic that might be included under this heading is the degree to which an S-I incentive automatically adjusts to a changing rate of inflation. Arguments in favor of proposals, for example, for accelerated depreciation, often turn on their ability to offset the current rate of inflation. The measures typically will be inappropriate for other rates of inflation, implying the necessity for further rule adjustments when conditions change. Other S-I incentives may be more or less robust to varying inflation rates. 


\section{A Classification of S-I Incentives}

As has been indicated, currently employed or discussed measures to encourage saving and investment can, with a little license, be placed in two broad categories, the class of consumption tax ("C-tax") rules and the class of direct grant rules. These rules in turn may be applicable to either real or financial assets, and they may apply to the purchase or sale of assets (a stock notion) or to the yield from assets (a flow notion). This generates an eight way classification.

The usual approach to implementing a consumption tax base ("standard" C-tax treatment) is to permit the taxpayer to deduct from a conventional income tax base the net purchase of assets during the accounting period. Various S-I incentive measures have this character, notably including accelerated depreciation of real assets (the standard C-tax treatment would carry acceleration to the logical extreme of immediate expensing). Contributions by employers to a qualified pension plan on behalf of employees are subject to the standard C-tax treatment, since the procedure is equivalent to paying out the contributions in wages and allowing the employees to deduct the amounts saved in this form. Subsequent pension dissaving upon retirement is then included in the employees' income tax base. Similar rules apply to saving through Keogh Plans and IRA's, further examples of S-I incentives of the C-tax type.

A classical consumption tax, levied at a constant rate over time for a given taxpayer, is equivalent in its effect to exempting the yield from saving or investing from the income tax, and I refer to this as the "alternative" method of implementing a consumption tax. This approach is also used in S-I incentives, particularly in the deferral of tax on capital gains accruing in 
either real or financial assets and in the reduced rate of tax imposed on such gains upon realization. Reducing the rate of corporation income tax can also be viewed as belonging in this class of S-I incentives with respect to real assets. The exclusion of dividend and interest receipts (up to a limit) from individual income tax represents an application of the alternative consumption tax treatment to financial assets. One might also include here the exemption of state and municipal bond interest, although this is evidently not a measure designed to encourage saving and investment generally.

In addition to these two consumption tax approaches on the markets for real and financial assets, we can distinguish incentives having the character of a direct grant, which is not subject to tax or equivalent to a deduction from the income tax base. The prime example of this in the U.S. is the investment tax credit (ITC), which provides the investor (who has sufficient tax liability), in effect, a cash grant equal to a fraction of the cost of a real asset. Unlike the closely related techniques of accelerated depreciation or immediate expensing of investment outlays, the subsidy provided by the ITC is independent of the investor's marginal tax rate.

There is no program in the U.S. system obviously corresponding to this with respect to saving in the form of financial assets. In other countries, there exist direct subsidies to saving of a character similar to the U.S. investment tax credit: the public treasury supplements individual savings by direct grants, independent of the recipient's marginal tax rate.

For completeness, we may note the possibility in principle of S-I incentives of the yield exemption type analogous to the investment tax credit. 
Such measures would involve providing the owner of real or financial assets with an extra return not subject to income taxation. We would then have four approaches to the subsidy of each of the two asset types, real and financial, a total of eight hypothetical subsidy techniques. Table 1 displays the eight-way classification. Cells 6,7 and 8 appear to be essentially empty in the U.S. today

In the next section, we look at the way these different incentive measures work, and interact, under conditions of stable prices (or well indexed income measurement rules, regardless of inflation).

Table 1

A Classification of Saving and Investment Incentives in an Income Tax System

\begin{tabular}{|c|c|c|c|}
\hline \multirow{2}{*}{\multicolumn{2}{|c|}{ S-I Incentive Type }} & \multicolumn{2}{|c|}{ Asset Type } \\
\hline & & Real & Financial \\
\hline \multirow[t]{2}{*}{$\begin{array}{l}\text { Comsumption } \\
\text { Tax } \\
\text { Rules }\end{array}$} & $\begin{array}{l}\text { Standard C-Tax } \\
\text { Rules }\end{array}$ & $\begin{array}{c}\text { (1) } \\
\text { Accelerated } \\
\text { Depreciation } \\
\text { Expensing R\&D }\end{array}$ & $\begin{array}{l}\text { (2) } \\
\text { Qualified Pension } \\
\text { Saving }\end{array}$ \\
\hline & $\begin{array}{l}\text { Alternative C-Tax } \\
\text { Rules }\end{array}$ & $\begin{array}{l}\text { (3) } \\
\text { Capital Gain Special } \\
\text { Rules }\end{array}$ & $\begin{aligned}(4) \\
\text { Capital Gain } \\
\text { Special Rules }\end{aligned}$ \\
\hline \multirow[t]{2}{*}{$\begin{array}{l}\text { Direct } \\
\text { Grant }\end{array}$} & $\begin{array}{l}\text { Grant for Purchase } \\
\text { of Assets }\end{array}$ & $\begin{array}{c}\text { (5) } \\
\text { Investment Tax Credit }\end{array}$ & $\begin{array}{l}\text { (6) } \\
\text { Savings Premium } \\
\text { Programs (not } \\
\text { U.S.) }\end{array}$ \\
\hline & $\begin{array}{l}\text { Supplement to } \\
\text { Asset Yield } \\
\text { (after taxes) }\end{array}$ & $\begin{array}{c}\text { (7) } \\
\text { No known examples }\end{array}$ & No known examples \\
\hline
\end{tabular}


II. S-I INCENTIVES IN THE ABSENCE OF INFLATION

Consumption Tax Incentives

To understand the way the different incentives work, how they differ and how they interact, we are best served by considering their application in a context with a minimum of complication. Therefore, we focus on the case of an investment with a risk-free return. To start with, assume away also the graduated structure of tax rates.

It will be sufficient, furthermore, for most of our purposes to study the impact of the various rules on one particular sort of real investment opportunity, the exponentially decaying machine. This is the model made familiar by Jorgenson and colleagues. 1 A new machine costing one dollar produces a rate of output valued at $c$, after allowing for payments to cooperating factors, and this is thus the rental rate a producer would be prepared to pay for the use of the machine. If the machine is of durability $\delta$ its rate of output declines at the constant relative rate $\delta$; the smaller $\delta$, the more durable the machine. The output rate of an s-year old machine is thus $c e^{-\delta s}$. Since an s-year old machine is just equivalent to $e^{-\delta s}$ new machines, economic depreciation takes place at rate $\delta e^{-\delta s}$. It is generally assumed that machines of different durabilities are in use at a given time, and their output rates will differ. When it is necessary to be explicit about this I write $c(\delta)$ for the output rate of a new machine of durability $\delta$.

Simple wealth maximizing considerations will determine who will wish to own machines under various conditions. If the market rate of interest is given by $i$, a capitalist subject to a marginal tax rate $m$, will base his

1 See, for example, Jorgenson [1963], Hall and Jorgenson [1967]. 
borrowing and lending on the after tax interest rate, (1-m)i. Such a taxpayer will be willing to offer for a new machine any amount up to the discounted (at rate $(1-m) i)$ sum of rental payments on the machine, net of taxes, plus depreciation allowances. This demand price for the real asset is a result of pure arbitrage considerations, and has nothing to do with the capitalist's time preference or propensity to save. Since the supply price of a machine is 1 , the elimination of arbitrage profit requires

$$
1=\int_{0}^{\infty}[(1-m) c+m \delta] e^{-(\delta+(1-m) i) s} d s
$$

Explicit integration leads from (1) to the familiar condition of equilibrium

$$
i=c(\delta)-\delta \text {. }
$$

We may describe as the social rate of return, $r(\delta)$, on an asset of durability $\delta$ the internal rate of return on a unit of consumption foregone. That is,

$$
1 \equiv \int_{0}^{\infty} c(\delta) \mathrm{e}^{-(\delta+r(\delta)) s} \mathrm{ds}
$$

Solving explicity gives us

$$
r(\delta)=c(\delta)-\delta \text {. }
$$

Conditions (2) and (4) tell us that in equilibrium with an income tax the social rate of return on investment in machines of different types is the same. The allocation is thus characterized by production efficiency. ${ }^{1}$ While

1 This has been shown by, among others, Samuelson [1964]. 
the common social rate of return in this equilibrium equals the interest rate, $i$, the savers receive a lower rate of return, $(1-m) i=(1-m) r$, whether they save in the form of financial or real assets. Note that as the marginal tax rate $\mathrm{m}$ does not appear in equilibrium condition (2), this analysis would continue to hold with different tax rates applicable to different capitalists. Accelerated Depreciation. Consider now the way the accelerated depreciation for tax purposes influences the equilibrium outcome. There is no single interpretation to be given to this notion, but a natural approach in this context is to assume that in reckoning income tax the capitalist is allowed to treat the machine with actual durability parameter $\delta$ as though it were of durability $\delta^{*}$. For example, since any likely measure of the average effective or expected lifetime of an asset of type $\delta$ will be inversely proportional to $\delta$, allowing investors to assume $\delta^{*}=2 \delta$ could be taken to represent a halving of service lives for tax purposes.

If the taxation of interest is as before, the no-arbitrage equilibrium condition with accelerated depreciation is given by

$$
1=\int_{0}^{\infty}\left[(1-m) c e^{-(\delta+(1-m) i) s}+m \delta^{*} e^{-\left(\delta^{*}+(1-m) i\right) s}\right] d s,
$$

which reduces to relationship (6) among rental rate, interest rate, and depreciation and tax parameters:

$$
c=\left(\frac{(1-m) i+\delta}{(1-m) i+\delta^{*}}\right)\left(i+\delta^{*}\right) .
$$


We may verify by substitution that if tax and economic depreciation are the same $\left(\delta=\delta^{*}\right)$, condition (6) reduces to (2). Increasing $\delta^{*}$ relative to $\delta$ reduces the equilibrium rental rate, given $i$, and results in the return to savers, (1-m)i, being higher in relation to the social rate of return, c- $\delta$. If accelerated depreciation is carried to the extreme of instantaneous write-off, $\delta *=\infty$, equilibrium condition (6) reduces to

$$
c=(1-m) i+\delta
$$

This is the characteristic equilibrium condition for a flat rate income tax system in which real investment is given standard consumption tax treatment. Since $c-\delta$ is equated over all durabilities, this equilibrium is characterized by production efficiency, and since $c-\delta=(1-m) i$, the return to the saver, $(1-m) i$, is just equated to the social yield on real investment. Note that in this equilibrium the market interest rate exceeds the social rate of return by the factor $1 /(1-m)$, so that the tax on interest just takes away the excess over the social return.

Returning to condition (6), we may inquire about the relationship between $\delta$ and $\delta *$ needed to assure that in equilibrium the social return, $c(\delta)-\delta$, is equated at some value $\bar{r}$ for all asset types, a condition for production efficiency. If we let $\delta^{*}(\delta)$ stand for the depreciation rate allowed under the tax laws when the true depreciation rate is $\delta$, a little algebra shows that production efficiency $(c(\delta)-\delta=\bar{r})$ requires a particular relationship,

$$
\delta *(\delta)=\left(\frac{(1-m)(i-\bar{r})+m \delta}{\bar{r}-(1-m) i}\right) i \text {. }
$$


It is assumed here that the rate of return to the saver, (1-m)i, is below the social rate of return on investment, $\bar{r}$.

Condition ( 8 ) may be more readily interpreted if we state the objective of the accelerated depreciation scheme to be obtaining a specified proportional difference, $\beta$, between the interest rate and the common social rate of return on investment, that is, to effect in equilibrium the relationship $\bar{r}=$ $(1-\beta)$ i. With this substitution, (8) becomes (assuming $\beta$ less than $m$ )

$$
\delta *(\delta)=\left(\frac{(1-m) \beta}{m-\beta}\right) i+\left(\frac{m}{m-\beta}\right) \delta .
$$

Increasing the degree of acceleration toward effectively eliminating the tax wedge between private and social return involves setting $\beta$ closer to $\mathrm{m}$. From (9), we see this does involve raising $\delta^{*}$ toward $\infty$, but (9) also tells us that to avoid inefficiency in the allocation of investment it is necessary to add a term, related to the interest rate, that itself tends to $\infty$. To get some sort of feel for the inefficiency which might be engendered by failing to calibrate the tax depreciation appropriately to the interest rate and the applicable marginal tax rate, consider the particular case described in Table 2. 
Table 2

Illustrative Acceleration Schedule and Effects of Using Simple Scaling

\begin{tabular}{|c|c|c|}
\hline $\begin{array}{c}\text { Actual Depreciation } \\
\text { Rate, } \\
\text { (percent) }\end{array}$ & $\begin{array}{c}\text { Neutral Accelerated } \\
\text { Depreciation, } \delta^{*}(\delta) \underline{1} / \\
\text { (percent) }\end{array}$ & $\begin{array}{c}\text { Social Return }(c-\delta) \\
\text { when } \delta^{*}=2.6 \delta \text { 织 } \\
\text { (percent) }\end{array}$ \\
\hline 2 & 10 & 10.3 \\
5 & 16 & 9.5 \\
10 & 26 & 9.0 \\
50 & 106 & 8.5 \\
\hline
\end{tabular}

As sumptions: $i=.12, \mathrm{~m}=.5,{ }^{n}=.25$

${ }^{1}$ Calculated according to text expression (9).

2 Derived from text expression $(6)$.

The first column of Table 2 shows the true depreciation rate of assets. The second shows the tax depreciation rate required to obtain the effect of a fiftypercent relief from a fifty percent marginal tax rate, if the before-tax interest rate is twelve percent. Notable is the fact that the ratio of tax depreciation to true depreciation rate, near 2 for assets with an expected lifetime of two years, rises to 5 for assets with expected fifty year lives. Depreciation of long-lived assets must be "more accelerated" than that of shortlived assets. Failing to calibrate the degree of acceleration in this way, by employing instead a simple proportional increase in depreciation rates, 
disadvantages more durable relative to less durable assets.

The third column of Table 2 illustrates this by showing the social rate of return in equilibrium on assets of different durabilities when instead of the usual acceleration scheme a simple proportional shortening of lives is employed. In this example the proportionality factor is set to achieve the same incentive effect as the neutral pattern for assets with an expected life of ten years. The result is a spread of roughly two percentage points, or twenty-five percent, between the equilibrium social return on the two-year asset and that on the fifty-year asset. This difference is the pure social gain that could be obtained at the margin by shifting investment from the least to the most durable assets in the table.

In assessing whether a given differential in rates of return or tax on rates of return is "large", it is well to keep in mind the proverbial power of compound interest. With fifty years of reinvestment at ten percent, $\$ 1$ accumulates to nearly $\$ 150$; at eight percent it accumulates to a little over $\$ 50$. It thus may make sense to be concerned about differences in equilibrium rates of return that appear to be small.

Before leaving this exercise in calculating tax depreciation rates we should note that the assumption we have employed of a fixed interest rate involves a sort of self-contradiction. In view of the arbitrage potential, a fixed interest rate implies a fixed incentive to save, unless the tax rate declines. If the new equilibrium is to involve a larger amount of consumption foregone, it will presumably require a higher interest rate. Presumably also, the tax rate will need to be higher than otherwise to cover the revenue losses 
to cover the revenue losses due to accelerated depreciation. If the tax depreciation rule is not well designed, it is possible that it would do no more than generate a higher interest rate, higher tax rate and some dead weight loss. 1 Much the same can be said of any S-I incentive.

While exponential depreciation does not encompass all investment opportunities, we can learn several lessons from this analysis. We see that a mechanical compressing of the life of an asset for tax purposes will not in general generate an appropriate balancing of incentives across short- and longlived assets, that the adjustment required to maintain efficient resource use may be moderately complicated to derive, and that it will in general depend upon the interest rate and the applicable marginal tax rate. However, the problem of designing a schedule of accelerated depreciation allowances is made to appear simpler in this case than it is when other possible patterns of the decline of asset value are taken into account. Fach alternative requires, in principle, its own version of (9).

Arguably, this says nothing more than that in this sphere as in others, there is a problem of choosing a sufficiently good approximation. A further oversimplification is not so easily dealt with. The marginal tax rate in the equilibrium condition, (6), and in the expression for a neutral acceleration schedule, (9), is not a constant. Taxpayers with different marginal tax rates will have different demand prices for the same real asset. Establishing equilibrium requires assuming constraints on arbitrage (for example, borrowing

1 For an example see Bradford [1980; pp. 42-50]. 
limits), or a mechanism that produces its own constraints. We shall return to this issue in the context of an alternative approach to the application of consumption tax rules to real investment.

Partial Expensing of Real Investment. We know that taxation according to income properly measured, using economic depreciation, does not upset the aspect of production efficiency which we are studying, nor does taxation according to consumption principles, which involves immediate expensing of investment outlays. One suspects then that a "mixture" of the two approaches, appropriately designed, should share this virtue. As Harberger [1979] has recently argued, such is indeed the case. 1

Specifically, consider the effect of allowing in this system the immediate expensing for tax purposes of a fraction $\alpha$ of the investment in the machine. This means that for given value of $i$, the demand price of the capitalist is increased by $m \alpha$ less the loss in value of depreciation allowances. If the basis for depreciation is reduced by just the amount expensed, elimination of arbitrage profits implies

$$
I=\int_{0}^{\infty}[(1-m) c+m(1-\alpha) \delta] e^{-(\delta+(1-m) i) s} d s+m \alpha .
$$

Again, explicit integration plus some algebra reduces (10) to

$$
c-\delta=(1-m \alpha) i \text {. }
$$

Thus, for the case of exponential depreciation (and this generalizes easily to all patterns of depreciation) equilibrium with a flat rate income tax

1 Auerbach [1979a] confirms this point for the case of exponential depreciation. 
allowing partial expensing of investment outlays, together with economic depreciation applied for tax purposes to the unexpensed basis, is characterized by production efficiency in the sense that the social rate of return to marginal investment in capital of all durabilities (in use) is the same, and given by $(1-m \alpha) i$. In this equilibrium the interest rate exceeds the social rate of return:

$$
i=\left(\frac{r}{1-m \alpha}\right)
$$

while the rate of return received by the saver in either form is

$$
(1-m)_{i}=\left(\frac{1-m}{1-m \alpha}\right) r .
$$

The relationship holding when immediate expensing of all real investment is allowed is found by setting $\alpha=1$, whereby $(1-m) i=r$. The return to the saver equals the social return. This repeats the result above that immediate expensing of investment accomplishes the elimination of the tax "wedge" on the return to saving and thus effects consumption taxation, even though interest income is subject to tax (and interest outlays are allowed as a deduction).1 Note, though, that, as in the case of accelerated depreciation, the single marginal tax rate now enters the equilibrium condition. If the relationship between the interest rate, $i$, and the equilibrium rental rate, $c(\delta)$, is given by (11), the demand price for a unit machine of a taxpayer with marginal

\footnotetext{
lThis was one of the methods proposed by the Meade Committee for implementing a consumption tax in the U.K., where the income tax is imposed at essentially a single flat rate for the great bulk of taxpayers. [Institute for Fiscal Studies, 1978; ch. 81.
} 
rate $m^{\prime}$, possibly different from $m$, will be given by

$$
\frac{\delta+\left(1-m^{\prime}\right)\left(1+\left(m^{\prime}-m\right) \alpha\right) i}{\delta+\left(1-m^{\prime}\right) i}
$$

This demand price (obtained by evaluating the right-hand side of (10) for m=m', given (11)), derived from pure arbitrage considerations, will be greater than the supply price, 1 , if $m^{\prime}>m$ and less if $m^{\prime}<m$. This accords with intuition, most clearly for the case $\alpha=1$. For we know that the application of consumption tax principles to the real investment amounts to exempting the yield from tax. Any taxpayer can then be assured the rate of return $r=c-\delta$. This will just equal the after tax interest rate for the taxpayer with marginal rate $\mathrm{m}$. For the taxpayer with rate $m^{\prime}>m$, the after tax return on lending or the cost of borrowing is less. Hence the situation presents an opportunity for arbitrage profit, with the high bracket taxpayer borrowing to finance the acquisition of machines, each time earning a pure profit at the expense of the tax system. Although one must be cautious about a mechanical interpretation of this model, it is instructive to push it to an equilibrium. Such is permitted by the impossibility of holding negative quantities of the real asset (short sales of real assets seeming too far fetched). Tax arbitrage profits are eliminated when the marginal rate applicable to equilibrium condition ( 11 ) is $m_{\max }$, the highest rate among taxpayers. At that point, all real assets are owned by top-bracket taxpayers, while the portfolios of lower bracket households are entirely in loans. The yield on saving by the top bracket taxpayer is related to the social return according to (13) (with $m=m_{\max }$ ) while taxpayers with lower 
rates obtain higher after tax yields in the usual way. Those with a sufficiently low marginal rate (below $\alpha_{\text {max }}$ ) receive a return on saving in excess of $r$. When $\alpha=l$, all taxpayers below the maximum tax bracket will have an after tax interest rate in excess of the social rate of return on investment. Adjusting the Treatment of Interest. The phenomenon of lightly taxed assets migrating to the portfolios of high bracket taxpayers is not a new discovery. What seems yet to be recognized is the possibility of offsetting the effect through varying the rate of inclusion of interest receipts in (and deduction of interest outlays from) the income tax base. That is to say, a partial standard consumption tax treatment of real investment will be compatible with an appropriately partial alternative consumption tax treatment of borrowing and lending. The argument is general, not dependent on the exponential depreciation assumption, and is simply a matter of discovering the inclusion rate needed to foreclose arbitrage profit.

Because of the tax rebate, the taxpayer with marginal rate $m$ can finance a fraction $m \alpha$ of the outlay on real assets by the tax reduction due to the immediate expensing of the fraction $\alpha$. In a pure arbitrage transaction the remainder is financed by borrowing at interest rate $i$. If a fraction $\gamma$ of interest payments is deductible from the tax base together with a fraction $(1-\alpha)$ of $d$, the decline in value of the asset during the period, the net of tax proceeds from rental will be $(1-m) c+m(\gamma(1-\infty) i+(1-\alpha) d)$. This must cover the sum of interest payments and the actual loss in asset value to the holder. The former is simply $(1-\alpha m) i$. The latter differs from d because of the treasury's claim on the value of the asset. A decline of $d$ in the market value of the 
asset implies a decline of $(1-\infty \mathrm{m}) \mathrm{d}$ in the value of the private owner's share. Thus the no arbitrage profit condition is given by

$$
(1-m) c+m(\gamma(1-\alpha m) i+(1-\alpha) d)=(1-\alpha m) i+(1-\alpha m) d
$$

which reduces to

$$
c=\left(\frac{(1-\gamma m)(1-m \alpha)}{1-m}\right) i+d
$$

The coefficient of $i$ in (16) will be identically 1 if

$$
\gamma=\frac{1-\alpha}{1-m \alpha}
$$

When the proportion of interest allowed as a deduction is given by $\gamma$, defined in (17), taxpayers in all brackets are indifferent between lending and purchasing real assets. The equilibrium interest rate just equals $c-d$, the social rate of return on real investment, and the rate of return received by the saver is $(1-m \gamma) i$. When $\alpha=1$, the purchasers of real assets are allowed immediate expensing. The corresponding value of $\gamma$ is zero: interest is not subject to tax. Both rules are precisely those of a consumption tax system with tax rates constant over time for each taxpayer, although graduated across taxpayers. When $\alpha=0$, real assets are allowed only economic depreciation as a deduction 
in calculating the tax base, the principle of true income taxation. In this case, $\gamma=1$; interest is taxed in full. Table 3 shows the values of $\gamma$ for various combinations of write-off rate and marginal tax bracket.

Table 3

Rate of Inclusion of Interest Income and Deduction

of Interest Expense Corresponding to

Various Rates of Expensing Real Investment

(percent)

\begin{tabular}{|c|c|c|c|c|c|}
\hline \multirow{2}{*}{$\begin{array}{l}\text { Fraction of Real } \\
\text { Asset Expensed } \\
\text { (percent) }\end{array}$} & \multicolumn{5}{|c|}{$\begin{array}{c}\text { Marginal Tax Rate } \\
\text { (percent) }\end{array}$} \\
\hline & 10 & 20 & 40 & 50 & 70 \\
\hline 0 & 100 & 100 & 100 & 100 & 100 \\
\hline 25 & 77 & 79 & 83 & 86 & 91 \\
\hline 50 & 53 & 56 & 63 & 67 & 77 \\
\hline 75 & 27 & 29 & 36 & 40 & 53 \\
\hline 100 & 0 & 0 & 0 & 0 & 0 \\
\hline
\end{tabular}

Entries are calculated according to text expression (12) for $\gamma$, with $\alpha=$ fraction of real asset allowed as immediate deduction and $\mathrm{m}=$ investor' $\mathrm{s}$ marginal tax rate.

The reader may verify that the demand price for a dollar's worth of exponentially depreciating real assets, given by the right-hand side of (10), is exactly one dollar, independent of the taxpayer's marginal rate, when the discount rate $(1-m) i$ is replaced by $(1-\gamma m) i$ and $c$ is replaced by the equilibrium value $i+\delta$. 
Cells (2) and (3). Thus far we have focussed on the interactions between standard C-tax treatment of real investment (cell (1) of Table 1) and alternative C-tax treatment of interest (cell (4) of Table 1). The analysis of standard C-tax treatment of financial assets (cell (2) of Table 1), typified by Keogh Plan saving is straightforward. As far as its interaction with the appropriate treatment of interest is concerned, the argument is basically the same as applied to real investment. The important difference is that there is now no possibility to equilibrate away tax arbitrage profits through a differential in the returns on the two forms of saving.

To illustrate, if saving in a pension plan could be used to secure a loan subject to conventional income tax rules, there would be a tax arbitrage profit obtainable through borrowing (to make the example particularly graphic, let it be from the pension fund itself) and depositing the funds, together with the tax refund due upon deducting the deposit, in the pension fund. This involves no change in consumption and no real change in portfolio. But the interest on the borrowing is deductible, while the interest on the offsetting "lending" is not taxed. Since the underlying asset is exactly the same, there is no possibility for this profit to be eliminated through yield differentials: the earnings of the fund are the interest paid on the borrowing. Controlling this arbitrage profit requires either direct limits on the arbitrage process or an offsetting change in the treatment of interest. (Another possibility is found in the endogenous adjustment of marginal rates over the life cycle; see Bradford [1980, pp. 47-49]). Current rules follow the first approach, setting ceilings on annual additions to tax-favored pension savings, restricting the pledging of pension wealth as loan collateral, prohibiting or 
penalizing withdrawal of funds before retirement, and so forth. While these rules no doubt inhibit arbitrage profit, they also tend to eliminate the incentive effect of the programs. An individual who has reached the ceiling confronts the usual $(1-\mathrm{m})$ i yield on incremental savings, as does one sufficiently deterred by the restrictions on the pension asset to stop short of the statutory ceiling. Significantly lifting these restrictions on the standard Ctax treatment of financial assets calls for associated changes in the taxation of interest, along the lines discussed in connection with the standard C-tax treatment of real investment.

Discussion of cell (3) of Table I requires a closer look at the rules for taxing sales of depreciable assets (importantly real estate) and certain tax favored activities, such as ship building and timber production. While there is no doubt an important story to be told here, it extends beyond my knowledge of the rules. However, we can readily see that there is a potential for "double-dipping," with assets subject to the incentive effects of both standard and alternative C-tax treatment. This would have the consequences of production inefficiency and portfolio distortion as a function of marginal tax brackets of the sort analyzed in connection with standard C-tax treatment of real investment with no change in the taxation of interest.

\section{Direct Grant Incentives}

We can move more quickly through the discussion of direct grant incentives since the basic analytical approach is now familiar. Furthermore, there is as a practical matter only one program in question, that of 
a direct subsidy to real investment expenditures. This happens to be administered through the tax system, in the form of the ITC. Two features distinguish it from a directly appropriated grant. First, the credit may only be applied to settlement of positive tax liability. This may mean the subsidy is not available to many firms at a given time. Certainly it introduces incentives for somewhat artificial financing arrangements and creates administrative complexity, an aspect of the ITC about which I have nothing new to say. Second, the subsidy is not reflected in the basis for depreciation. That is, while the cost of an asset to the taxpayer is the price net of tax credit, depreciation allowances are calculated as though the full price had been paid. This is nothing more than a mismeasurement of income, and the appropriate analysis is the same as that above in connection with accelerated depreciation.l

Zero arbitrage-profit equilibrium with an ITC correctly calibrated for durability, together with allowances for depreciation calculated on the basis of the purchase price of the asset net of tax credit, will be characterized by production efficiency in the sense we have been using, and neutrality with respect to the portfolios of wealth holders. The latter property, indeed, depends only on the use of economic depreciation (of the net of credit asset value) for tax purposes. We may see these conclusions easily in the exponential depreciation case, where the elimination of arbitrage profits requires

$$
I=\int_{0}^{\infty}[(1-m) c+m(1-k) \delta] e^{-(\delta+(1-m) i) s} d s+k,
$$

I An early treatment of this is found in Brown [1962]; for further details see Bradford [1979]. 
where $\mathrm{k}$ is the fraction of the unit purchase price of the asset available as a credit against tax. Upon explicit integration and simplification, this condition reduces to

$$
c-\delta=(1-k) i-k \delta
$$

We see that, as $m$ does not appear in the equilibrium condition, arbitrage profit opportunity is eliminated for individuals in all tax brackets by (19). However, to obtain equality of the social rate of return, c- $\delta$, over all asset types, $\delta$, in use in equilibrium, a particular relationship, $k(\delta)$, between the credit rate and the durability of the asset is required. It follows from (19) that to obtain a given value, $\bar{r}$, of the social rate of return requires $k(\delta)$ to satisfy

$$
k(\delta)=1-\left(\frac{\bar{r}+\delta}{i+\delta}\right)
$$

This relationship is illustrated in Table 4. In the second column are shown the credit rates necessary to obtain a social rate of return of 9 percent where the associated interest rate is 12 percent, assumptions paralleling those of Table 2. (The savers thus receive a rate of return of 
(l-m)12 percent, depending upon individual marginal tax rates.) It will be seen that a considerable variation is required to implement a subsidy that does not distort the choice of asset lives. To give an idea of the effect of failing to take into account the need to calibrate the credit for durability, the third column of Table 4 shows the social rate of return on assets of different lives when a flat rate credit of 13.6 percent is applied uniformly. This is the credit rate which induces a social yield of 9 percent for an asset with a ten-year expected life (still assuming an interest rate of 12 percent). Because of the bias toward short-lived assets this entails, investment in less durable assets is driven to the point of very low social yield (it would go to zero for an asset with zero life) while the social rate of return on long-lived assets exceeds 9 percent (tending to 10.4 percent for a non-depreciating asset).

Table 4

Illustrative Neutral Tax Credit Schedule and Equilibrium Social Rate of Return Using a Flat Rate

\begin{tabular}{|ccc|}
\hline $\begin{array}{c}\text { Actual } \\
\text { Depreciation } \\
\begin{array}{c}\text { Rate, } \delta \\
\text { (percent) }\end{array}\end{array}$ & $\begin{array}{c}\text { Neutral ITC } \\
\text { Ratel } / \\
\mathrm{k}(\delta) \\
\text { (percent) }\end{array}$ & $\begin{array}{c}\text { Social Return }(\mathrm{c}-\delta) \text { ) } \\
\text { When } \mathrm{k}(\delta)=.136 \text { I }\end{array}$ \\
\hline 2 & 21.4 & 10.1 \\
(percent) \\
10 & 17.6 & 9.7 \\
50 & 13.6 & 9.0 \\
\hline
\end{tabular}

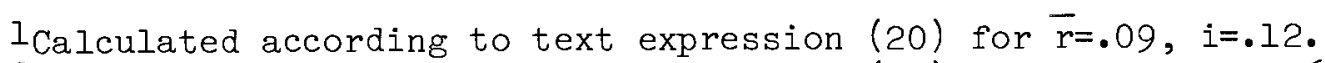

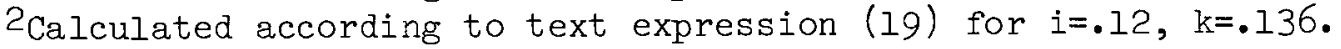


Certain general conclusions emerge from this discussion of direct grant incentives for the purchase of real assets. First, if economic depreciation of the net of credit cost of the asset is employed in calculating taxable income, we do not encounter differential effects on the demand price for assets as a function of the applicable marginal tax rate -- effects which called for a change in the taxation of interest under the consumption tax approach to S-I incentives. A corollary is that increasing the rate of credit does not affect the relative taxation of the returns to saving as $\mathrm{m}$ varies across taxpayers. In the case of the consumption tax approach, as the level of incentive is increased, the rate of return on consumption forgone obtained by all savers tends toward equality with the social yield on investment. In the direct grant approach, as the subsidy level is increased the whole structure of individual rewards to saving goes up relative to the social return on investment, but there is no tendency toward equating the private yields of taxpayers in different marginal rate brackets.

Designing a credit structure to avoid production inefficiency may be difficult. I While in the particular case of exponential depreciation the formula is not particularly complex, it requires knowledge of both the target social rate of return and the interest rate that will call forth the private saving necessary to generate precisely that rate of return. Furthermore, a different formula applies to each pattern of depreciation. 2 In view of the dif-

I E. Cary Brown [1962] shows that one way to achieve the correct calibration of the credit is to structure it as flat "net credit," that is, a fixed percentage of the difference between the cost of the machine and the present value (at the net of tax interest for that investor) of economic depreciation allowances. Since this is equivalent to calibration of the "gross credit," it is subject to the same problems.

2 For examples of the formulas applicable to other patterns of depreciation see Bradford [1979]. 
ficulty tax authorities have in determining the facts about depreciation, a requirement that the credit rules be written with a detailed knowledge is a severe one.

Finally, we may note that the consumption tax approach to S-I incentives tends to substitute rules with few measurement problems for the income tax rules which are subject to many problems. The greater the C-tax type of incentive, the less important are the shortcomings of the income tax residual. The direct grant approach does not share this property.

\section{S-I INCENTIVES WITH INFLATION}

\section{Background on Inflation and Taxation}

The previous section considered the properties of various S-I incentive measures under conditions of stable prices. Inflation brings with it new problems of income measurement. 1 An ideal indexing system would solve those problems, and if we had such a system, the preceding analysis would be all that were needed. We do not, however, and the notion that an extra tax on the reward to saving is a consequence of inflation has motivated much of the recent movement to enact S-I incentives. In this section we consider, still in the simple model, the consequences of steady state inflation and the effectiveness of various measures to offset it.

To start with, let us review the way in which an unindexed tax system affects the equilibrium in the market for real assets, first in a flat rate tax system. With a steady rate of inflation $\pi$, the nominal flow of rentals obtained from a machine of age $s$ is ce $(\pi-\delta) s$, while under historic cost depreciation the allowance for tax purposes is $\delta e^{-\delta s}$. The no-arbitrage-profit condition becomes

1 For a general treatment see Stiglitz [1980]. 


$$
I=\int_{0}^{\infty}\left[(I-m) c e^{(\pi-\delta-(I-m) i) s}+m \delta e^{-(\delta+(I-m) i) s]} d s\right.
$$

Provided $\pi$ is less than $\delta+(I-m)$, this condition can be reduced to

$$
c=\left(\frac{\delta+(1-m) i-\pi}{\delta+(1-m) i}\right)(i+\delta)
$$

When $\pi=0$ this reduces in turn to condition (2).

We can see from (22) that with historic cost depreciation and no indexing of interest inflation influences both the relative social yields from assets of different durabilities and the real return received after taxes by savers. The latter is given by $(1-m) i-\pi$, and thus whether it is increased or decreased by inflation depends upon whether the equilibrium interest rate increases by more or less than $l /(I-m)$ per point increase in inflation. $I$ Letting $\hat{i}$ stand for the real interest rate, such an adjustment would imply

$$
i=\hat{i}+\frac{\pi}{I-m} \quad \text {. }
$$

An adjustment of this magnitude is apparently counter factual in the U.S. recently. But we might ask whether it is likely even in our simple analytical model. Such an adjustment would imply no change in the equilibrium. productivity, c, (also called the "gross rental rate") of non-depreciating

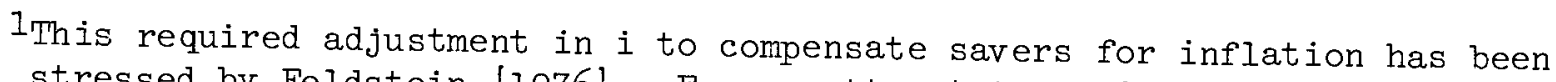
stressed by Feldstein [1976]. For an attempt to rationalize the fact that interest rates have moved with inflation at most according to Fisher's law (point for point) in the U.S. in recent years see Feldstein and Summers [1978]. Feldstein, Green and Sheshinski [1978] explore models of interest determination under conditions of inflation. Stiglitz [1980] has emphasized that with imperfect indexing the incidence of inflation depends upon the measures taken to maintain adherence to the government's budget constraint. General conclusions about the effect of inflation thus require modeling the
government's reaction. 
machines, as can be verified by substitution of (23) into (22) for the case of $\delta=0$. The same analysis leads to the conclusion that the equilibrium gross rental rate (and hence the social rate of return) would necessarily rise for all other durabilities. If the law of diminishing returns applies to investments of different durabilities, this condition would imply a reduction in the capital stock in the aggregate. If the capital stock desired by private wealth holders is a declining function of the private rate of return, this is incompatible with the assumption, expressed in (23), of a constant value of $(1-m) i-\pi$. In this sense there is a presumption that, absent correction of income measurement, inflation will lead to a decline in the real private rate of return, (1-m)i- $\pi$, a decline in the overall capital stock, but an increase in the stock of the most durable forms of capital.

This is in accord with Auerbach's [1979] analysis but in contrast to Feldstein's [1980] view that inflation biases the pattern of investment in favor of short-lived assets. The basis for Feldstein's conclusion is the behavior of what he terms the "net cost" of a dollar of investment, defined to be one minus the sum of the investment credit and the present value of real depreciation allowances, where a constant real discount rate is employed in the evaluation. If we let $r$ stand for the latter rate, $k(\delta)$, the investment credit allowed for a machine of durability $\delta$, and $\mathrm{C}_{\mathrm{H}}$ the net cost per dollar of investment under historical cost depreciation,

$$
\begin{aligned}
C_{H} & =1-\int_{0}^{\infty} m \delta e^{-(\delta+r+\pi) s} d s-k(\delta) \\
& =1-\frac{m}{\delta+r+\pi}-k(\delta) .
\end{aligned}
$$


Clearly the net cost of neither an infinitely durable asset ( $\delta=0)$, nor an instantaneously depreciating asset $(\delta=\infty)$, is affected by inflation. In between an increase in $\pi$ increases $C_{H}$, with the relative increase rising and then falling with $\delta$. The range of parameter values considered by Feldstein was drawn mostly from the rising segment of this relationship.

A shortcoming of this approach is that it leaves unexplained the discount rate used by investors, which is treated as a given. In our analysis, the discount rate is a market price and its place in the calculation is determined by pure arbitrage considerations. As a market price, the discount rate may itself be influenced by the economic environment, including the rate of inflation. I find the arbitrage argument persuasive, particularly where (as in both analyses) debt and real investment are treated as though riskless.

All of the analysis thus far is based on the assumption of a single marginal income tax rate, $m$. We can see from (22) that with unadjusted depreciation, the demand price for investment goods will vary with the tax bracket of the investor. The rental rate in (22), which is the minimum required to cover taxes, depreciation and interest, declines with $\mathrm{m}$. If the rental rate and interest rate are such as to permit a taxpayer with marginal tax rate $m$ to break even (on purchase of a machine of given durability), taxpayers in higher brackets will have an opportunity for pure arbitrage profit through borrowing to finance real investment while low bracket taxpayers will want to sell machines and lend. This is a situation similar to that discussed above. In that case equilibrium in the model required all real investment to be in 
the hands of top-bracket taxpayers. While to elaborate on the details would require more space than merited, there does not seem to be any analagous way of achieving equilibrium in this case. Just how actual markets clear is not obvious, but it is safe to say that without without correction of income measurement for tax purposes inflation generates distortions in the composition of both the real capital stock and individual portfolios.

Inflation Adjustment. Full inflation adjustment of the accounts would involve, first, converting all dollar amounts in the calculation of the tax to consistent units, that is, dollars of equal purchasing power. A natural choice of units is current dollars. Inflation adjustment thus calls for increasing the basis of assets sold in the calculation of capital gains and in the determination of depreciation allowances, as well as for similar changes in inventory accounting. These adjustments are conceptually straight forward.

Less obvious are the changes called for in the treatment of interest. In principle, the value of the lender's asset after the payment of interest is exactly what it was at the beginning of the period. Payments considered "interest" in the usual income tax rules are intended to have this character, and, by and large, they do when prices are stable. Thus, if a depositor withdraws the interest paid by a savings bank during a year, the nominal balance is constant. Regarding this interest as income is thus correct when there is no inflation, but when there is inflation it overstates the income of the depositor and understates that of the bank by the loss in purchasing power of the nominal balance over the year. Correcting the accounts calls for associating with interest payments a sum corresponding to the bank balance -- presumably one would call it the "principal" -- and allowing the creditor a deduction for the loss in purchasing power of the principal during the year, while 
assessing the debtor with additional income in equal amount. ${ }^{1}$

Following this procedure, the net of tax interest rate, i.e., the discount rate applicable to nominal cash flows, becomes $(1-m) i+m \pi$. In the case of steady inflation, this is equivalent to adjusting interest payments to reproduce the effect of taxing on the basis of the real interest rate, $i-\pi$. It may be readily verified that adjusting both the real and the financial sides of the accounts in this way restores the calculus of equilibrium to full equivalence to the no inflation case with the same real interest rate. Because the adjustment of interest called for involves equal and opposite changes in the tax bases of debtors and creditors, precisely the same economic effect can be accomplished by a change in the interest rate in a flat-rate tax world. To see this, note that with only depreciation allowances adjusted condition (21) becomes

$$
I=\int_{0}^{\infty}[(1-m) c+m \delta] e^{(\pi-\delta-(1-m) i) s} d s
$$

which reduces to

$$
c=i+\delta-\frac{\pi}{1-m} \text {. }
$$

1 For detailed discussions of the problems of indexing the income tax for inflation see Aaron [1976], Bulow and Shoven [1975; 1976], Fabricant [1978]. 
Since (26) implies $c-\delta$ is the same for all $\delta$ we conclude that indexing real investment accounting will restore the property of production efficiency to capital market equilibrium. If, furthermore, the nominal interest adjusts according to (23), (25) implies in turn that

$$
c=\hat{i}+\delta \text {, }
$$

which is to say the real rental rate and after tax real interest rate are unaffected by inflation. Note again the large responsiveness of the interest rate to inflation required to obtain this outcome. The nominal rate must increase by enough to cover the inflation premium plus the tax due on that premium.

Unfortunately, if marginal tax rates vary across individuals, condition (26) tells us that portfolio distortion is still a problem. There will be opportunities for tax arbitrage profits, with high bracket taxpayers borrowing to buy real assets and low bracket taxpayers selling real assets to lend at interest. The result is pressure toward the sorting of portfolios along lines already discussed.

To sum up, it is possible by reasonably simple methods to correct for the effects of inflation on the tax base arising from real investment. Furthermore, this would be sufficient in a flat rate tax system, provided nominal interest rates were sufficiently flexible. However, with graduated rates, there will be portfolio biases unless the treatment of interest is adjusted as well. This is a much more difficult matter administratively. Current discussion of S-I incentives emphasizes their potential to offset inflation. 
One objection to this is obvious, that an incentive designed to offset one inflation rate will be inappropriate at another. Not so widely recognized is the fact that none of the measures under consideration addresses the need to simulate correction of interest transactions. Hence as we consider next the properties of S-I incentives under inflation, we know that this is one problem which they will not solve.

\section{S-I Incentives and Inflation}

The way in which accelerated depreciation or the investment credit fits into this scheme requires no new analytical materials. From the discussion thus far, we know that these measures can not provide a general solution to the problems posed by inflation. The situation calls for a second-best analysis, to determine whether they could effect an improvement on equilibrium with existing rules.

The principal difficulty seems to be modeling the effect of inflation on the interest rate. It is tempting to deal with this by appealing to the observation that the interest rate moves roughly point-for-point with the inflation rate. However, consideration of the problem of setting depreciation allowances to maintain a fixed rate of return under this assumption simply draws attention to the paradox that it represents, namely, an inexplicably low nominal interest rate. For the adjustment required is a cut in depreciation allowances.

To see this, let $\delta *$ be the depreciation rate allowed for tax purposes. The zero arbitrage profit equilibrium condition, under the assumption of Fisher's law, is then 


$$
I=\int_{0}^{\infty}\left[(1-m) c e^{(\pi-\delta-(1-m) i) s}+m^{*} e^{-\left(\delta^{*}+(1-m) i\right) s}\right] d s .
$$

We can see that setting the tax depreciation allowance below the economic level to the extent of the inflation rate, that is $\delta^{*}=\delta-\pi$ (making the tax depreciation rate negative for the most durable assets), leads the equilibrium condition to reduce to

$$
c=i+\delta^{*},
$$

and since, by assumption, $i=\hat{i}+\pi$, where $\hat{i}$ is the real interest rate, this in turn implies

$$
c=\hat{i}+\delta \text {. }
$$

To rationalize Fisher's law thus calls for, in effect, taking into the tax base the purely nominal capital gains on real assets, and under this condition, real investment will be unaffected by inflation.

The difficulty is in explaining how the assumed relationship between interest rate and inflation rate could characterize equilibrium without the noted cut in depreciation allowances. My conjecture is that the apparent validity of Fisher's law results from some combination of failing to account correctly for the riskiness of debt and incomplete adjustment of markets. 
The analysis above of equilibrium under C-tax treatment of real investment and graduated rates suggest we should anticipate an interest rate adjustment close to that required to maintain the after-tax real return to high bracket taxpayers. Jorgenson has also recommended working with the assumption that the corporate tax rate, or a marginal tax rate of roughly 50 percent, would dominate the arbitrage between the real capital and lending markets. Whereas Fisher's law asserts a point for point adjustment of minimal interest to inflation, this assumption involves a $1 /(1-\mathrm{m})$ point increase in nominal interest rate per point increase in the inflation rate. We know that indexing real investment returns will justify this result and lead to efficient investment. In view of the difficulty of implementing indexation however, we may wish to consider acceleration as an approximation if the rate of inflation is expected to be constant.

It turns out that for the exponential depreciation case this is relatively simple. After integration and some algebra the zero-arbitrage-profit equilibrium condition (28), when combined with our interest rate assumption, can be written as:

$$
\text { , } c-\delta=\hat{i}+\left(\frac{1-\operatorname{sem}}{1-m}-1\right) \delta \text {, }
$$

where

$$
\Omega=\left(\frac{(1-m) i+\delta-\pi}{(1-m) i+\delta^{*}}\right) \frac{\delta^{*}}{\delta} .
$$

In order that the equilibrium with inflation rate, $\pi$, be the same as that with zero inflation, tax depreciation, $\delta^{*}$, should be set to render zero the coefficient of $\delta$ on the right-hand side of (31). This in turn requires setting $\delta^{*}$ according to the formula: 


$$
\delta *=\left(\frac{(1-m) \hat{i}+\pi}{(1-m) \hat{i}}\right) \delta .
$$$$
-43-
$$

Note that under this interest rate adjustment assumption an increase in depreciation allowances is called for. The required adjustment is rather sensitive to the assumed real interest rate, $\hat{i}$. For example, for $m=.5, \hat{i}=.09$ and $\pi=.1$, (32) implies the tax depreciation rate should be about three times the economic rate; for $\hat{i}=.03$, tax depreciation should be at nearly eight times the economic rate. To get a feel for what this might mean in terms of service lives, we might interpret the "life" of an exponentially depreciating asset to be the point at which more specified fraction (eq. 7/8) is exhausted. This would imply service lives inversely proportional to $\delta$. Thus (32) would call for assets to be depreciated (on a declining balance basis) assuming lives roughly one third of those used in the absence of inflation for $\hat{i}$ assumed equal to nine percent, one eighth for $\hat{i}$ assumed to be three percent.

\section{C-Tax Rules and Inflation. One of the virtues of consumption tax}

rules is their indifference to inflation. A numerical example will make this clear. Take the case of an individual with a 50 percent marginal rate who wishes to save $\$ 100$. Under the standard C-tax rules, he would nominally "save" $\$ 200$, but would receive a tax rebate of $\$ 100$ due to the resulting deduction, thereby forgoing just $\$ 100$ in consumption. With stable prices and a 10 percent interest rate, the $\$ 200$ would increase to $\$ 220$ by the end of a year. The individual now has the option of "dissaving" $\$ 220$, paying the associated tax of $\$ 110$ and increasing consumption by $\$ 110$, thus obtaining the full 10 per cent return on postponed consumption. By the alternative C-tax rules of exempting the yield on saving, the ten percent return is obtained directly. 
Now suppose the situation is one of 100 percent per annum inflation. If the real interest rate is unchanged, $\$ 100$ set aside in the first period will increase to $\$ 220$ in the second period. The saver subject to the alternative Ctax rule of yield exemption obviously continues to receive a 10 percent real yield on consumption foregone. This is so because the $\$ 100$ given up in the first period is equivalent to the $\$ 200$ return of principal in the second period, while the $\$ 20$ interest is equivalent to $\$ 10$ of first period consumption. The same outcome obtains for the saver subject to standard C-tax treatment. The $\$ 200$ "saving" involves foregoing $\$ 100$ of consumption in the first period, while "dissaving" of the $\$ 440$ accumulated by the second period is divided between $\$ 220$ in taxes and $\$ 220$ of increased consumption, exactly the same terms enjoyed by the conventional saver with exempt returns. It is thus the case that the real effect of a flat rate C-tax system is independent of the rate of inflation. The same thing will hold for a graduated rate system in which the rate structure is corrected for inflation. This adjustment, the easy part of inflation indexing, is sometimes called in the tax policy jargon "type I indexing," and it is the only sort of tax correction that seems to have a significant political appeal. Absent type-I indexing there is a tendency for inflation to subject the future dissaving corresponding to current saving to a higher rate of tax, and thereby inflation may interact even with C-tax rules.

We may easily verify the propositions about flat-rate C-tax rules under inflation for the case of exponential depreciation. With the interest 
rate adjusting point for point with the inflation rate, the no-arbitrage-profit condition with standard C-tax treatment of real investment and no inclusion or deduction of interest becomes

$$
I=\int_{0}^{\infty}(1-m) c e^{(\pi-\delta-(\hat{i}+\pi)) s} d s+m,
$$

which reduces, as expected, to

$$
c-\delta=\hat{i}
$$

While full application of C-tax rules is simultaneously an S-I incentive and a cure for inflation-induced measurement problems, partial application of C-tax rules, involving partial expensing of new investment and partial inclusion of interest income in the tax base, only partially solves these problems. The portion of the investment that is in effect taxed as income is subject to all of the difficulties due to defects in income measurement, including those associated with inflation. These include increased effective rate of taxation with inflation and pressure on portfolio composition, with high bracket taxpayers seeking to borrow from low bracket taxpayers to finance purchase of real assets. This suggests the continued importance of developing rules to measure income correctly or to impose a tax burden on investment equivalent to that resulting from correct income measurent. 
The Auerbach-Jorgenson First-Year Write-Off Scheme

In this connection it is appropriate to digress from the subject of S-I incentives to consider a suggestion put forward recently by Alan Auerbach and Dale Jorgenson [1980].1 They address themselves to the notion that correcting depreciation allowances for inflation is too complex for practical administration. Under their proposal, as an alternative to current deduction of inflation-adjusted depreciation allowances, investors are allowed a single deduction at the time of acquisition of the asset equal to the present value of the appropriate stream of real depreciation deductions, where a real discount rate is applied in the calculation. This procedure is intended to accomplish the effect of indexing historical-cost based depreciation allowances for changes in the general price levels but to be simpler in implementation. Such complexity as there is is embodied in the derivation of tables by the tax authorities, specifying the allowance for each type of asset.

The characteristics of this scheme emerge immediately if we note that it involves eliminating the current depreciation allowances, as seen in the term $\delta e^{(\pi-\delta-(1-m) i) s}$ in the cash flow stream of expression (25) for the current-depreciation adjustment case, and replacing them with a lump sum initial deduction of

$$
\int_{0}^{\infty} \delta e^{(\tilde{\pi}-\delta-(1-m) \tilde{i}) s} d s
$$

1 According to Joseph Pechman [1980] the Auerbach-Jorgenson proposal is a rediscovery of an idea of Nicholas Kaldor. 
where the tildas on $\pi$ and $i$ indicate the use of forecasted values of these variables. It follows immediately that the two schemes are wholly equivalent if the term $\tilde{\pi}-(1-\mathrm{m}) \tilde{i}$ is equal to $\pi-(1-m)$ i. The practical promise of the method, insofar as a reasonably exact substitute for inflation indexing is desired, depends upon determining the correct value of $\tilde{\pi}-(1-m) \tilde{i}$.

This involves two difficulties. First is the necessity to employ a discount factor taking into account the individual tax bracket of the investor. Second is the necessity to incorporate the relationship between $\pi$ and $i$ to the adjustment. As we have seen this is problematical. The scheme works out precisely if the taxation of in terest is also adjusted for inflation. Then the real after-tax interest rate for all taxpayers will be $(1-m) \hat{i}$, and this replaces $-\left(\tilde{\pi}_{-}(1-m) \tilde{i}\right)$ in calculation of the first year depreciation allowance. Since $\hat{i}$ is tyically assumed constant, it is reasonably straightforward to adjust the allowance for differences in $\mathrm{m}$, if $\mathrm{m}$ is known. Table 5 illustrates under the assumption $\hat{i}=.03$. To give an idea of the sensitivity of the scheme to the discount rate assumed, Table 5 also shows the allowances for $\hat{i}=.09$. 
Table 5

Illustrative First Year Deduction

Under the Auerbach-Jorgenson Approach

\begin{tabular}{|c|c|c|c|c|c|}
\hline \multirow{2}{*}{$\begin{array}{l}\text { Depreciation } \\
\text { Rate, } \delta \\
\text { (percent) }\end{array}$} & \multicolumn{5}{|c|}{$\begin{array}{c}\text { Marginal Tax Rate, m } \\
\text { (percent) }\end{array}$} \\
\hline & 10 & 20 & 40 & 50 & 70 \\
\hline 2 & $\begin{array}{c}43 \\
(20)\end{array}$ & $\begin{array}{c}45 \\
(22)\end{array}$ & $\begin{array}{c}53 \\
(27)\end{array}$ & $\begin{array}{c}57 \\
(31)\end{array}$ & $\begin{array}{c}69 \\
(43)\end{array}$ \\
\hline 5 & $\begin{array}{c}65 \\
(38)\end{array}$ & $\begin{array}{c}68 \\
(41)\end{array}$ & $\begin{array}{c}74 \\
(48)\end{array}$ & $\begin{array}{c}77 \\
(53)\end{array}$ & $\begin{array}{r}85 \\
(65)\end{array}$ \\
\hline 10 & $\begin{array}{c}79 \\
(55)\end{array}$ & $\begin{array}{c}81 \\
(58)\end{array}$ & $\begin{array}{c}85 \\
(65)\end{array}$ & $\begin{array}{c}87 \\
(69)\end{array}$ & $\begin{array}{c}92 \\
(79)\end{array}$ \\
\hline 50 & $\begin{array}{l}95 \\
(86)\end{array}$ & $\begin{array}{c}95 \\
(87)\end{array}$ & $\begin{array}{c}97 \\
(90)\end{array}$ & $\begin{array}{c}97 \\
(92)\end{array}$ & $\begin{array}{c}98 \\
(95)\end{array}$ \\
\hline
\end{tabular}

Entries (in percent) show the percentage first-year write-off equivalent to economic depreciation allowances, calculated according to the formula $\delta /(\delta+(1-m) \hat{i})$, where $\hat{i}$, the real interest rate, is assumed $=.03$. Figures in parentheses show the allowance assuming $\hat{i}=.09$.

For both corporate and individual taxpayers there may be a question about what marginal rate to employ in setting the first-year allowance. This difficulty also arises in the application of the adjustment of the interest deduction discussed above to coordinate with partial C-tax treatment of real investment. In that context, it may be acceptable to use the taxpayer's current marginal rate. In the Auerbach-Jorgenson scheme, however, more may well be riding on the rate chosen, because it affects the taxation of the entire asset purchase price and not one year's yield. Thus problems caused by variations over 
the life cycle and variations which might be induced by the deduction itself (shifting the taxpayer to a lower bracket) may require resort to approximations. While the discussion thus far incorporates the basic principle of the Auerbach-Jorgenson first year allowance, their actual proposal does not discriminate according to the investor's marginal tax rate. Allowances are based instead on the present value of depreciation deductions using the same discount rate in all cases, and thus are uniform for all taxpayers. One way to view this is as an approximation to the theoretical model. If the allowance corresponds to the ideal for a fifty percent marginal rate investor, for example, we see from Table 5 the deduction will be "too large" for a lower bracket taxpayer, and "too small" for a higher bracket taxpayer. Correspondingly there will be a tendency for arbitrage to move the real assets toward low-bracket portfolios, debt toward high bracket portfolios. Futhermore, if the allowances are "just right" for the fifty percent investor, they will not be correctly calibrated with respect to durability for the lower bracket investors, providing relatively too much incentive to purchase short-lived assets.

The first year allowances summarized in Table 5 are predicated on the assumption of expotential depreciation. Other depreciation patterns would, strictly speaking, call for different allowances; otherwise some inefficiency in the composition of investment would be expected. 1 Much the same issue has already been discussed above in connection with investment credit. In the present state of knowledge about depreciation there is unlikely to be anything

1 Different depreciation patterns would also require different "recapture rules" applicable to sale of assets, a subject we shall not pursue here. 
practical to be done about it.

Because under the Auerbach-Jorgenson scheme the full allowance for depreciation is taken in the first year its real value is wholly insensitive to the rate of inflation. I As we have noted, if interest payments and receipts are adjusted for inflation, and if the correct value for the real interest rate is employed in the formula, the Auerbach-Jorgenson first-year allowance just duplicates the effect of indexing annual depreciation deductions. Otherwise, and in particular without correction of interest payments and receipts, the effect will not be identical. If the first year allowances are based on an assumed real interest rate $\hat{i}$, but nominal interest is fully taxed and deductible, the noarbitrage-profit equilibrium condition is given by

$$
c=\frac{\delta+(1-m) i-\pi}{\delta+(1-m) \hat{i}}(\hat{i}+\delta) .
$$

This equilibrium condition is to be compared with (26), the condition when depreciation is actually indexed but interest is not adjusted. Even with a single flat rate of tax, the two are not identical unless nominal interest adjusts according to (23). In addition, it should be stressed that under neither approach to insulating the accounting for income from real assets from inflation can the system reproduce the effect of adjusting interest payments and receipts when there are different marginal tax rates. This will always result in pressure for low bracket taxpayers to sell real assets to lend and high bracket taxpayers to borrow to buy real assets.

IThere is a frequently-overlooked but practically highly significant condition in this statement: the investor must have sufficient taxable income gross of the depreciation deduction to make use of it. 
The Auerbach-Jorgenson first year allowance is not, strictly, an S-I incentive measure. It is a procedure for approximating the indexation of depreciation allowances for inflation. It would, however, be a simple matter to combine the first-year depreciation allowance with a partial first-year expensing of investment or with an investment credit and thus realize any desired degree of S-I incentive. A flat credit on the difference between the cost of the new asset and the first year allowance would maintain production efficiency. ${ }^{I}$ In the case of partial expensing the entire deduction would be available in the first year, but it would consist of the desired fractional write-off of the investment, with the remaining fraction eligible for the Auerbach-Jorgenson allowance. As this approach represents simply a combination of two measures already discussed, it requires no fresh analysis.

\section{SUMMING UP}

In this paper, I have suggested an eight way classification of saving and investment incentives. Perhaps the most fundamental is the division into the class of consumption tax treatments and the class of direct grants. Roughly speaking, the former includes measures, such as accelerated depreciation and tax sheltered retirement savings plans, which increase deductions or reduce inclusions in the income tax, while the latter includes measures, primarily the investment credit, providing an incentive not directly related to the investor's income tax circumstances. The difference between the two classes is of importance primarily when tax rates vary in the population of savers and investors.

1 This is thus a "net credit," as discussed in footnote 1, p. 32. I would like to thank E. Cary Brown for pointing out to me the natural adaptivity of the net credit to the Auerbach-Jorgenson proposal. 
It proved possible for us to reach some fairly general conclusions about the way incentives of the two classes operate. As to the broad characteristics of the outcomes under the two approaches, we saw that increasing levels of consumption tax incentives tend to lead to a convergence of the returns received by savers toward the social rate of return on investment. At the same time, because the process has the effect of displacing the income taxation of the returns to saving, income measurement problems, including inflation correction, tend to diminish in importance. Consumption tax incentives can also be relatively simple to design. While this does not hold for accelerated depreciation, we saw that expensing immediately a specified fraction of investment outlay, together with a reduced inclusion of interest receipts, provides an incentive without distorting either investment choice (among assets of different durabilities) or portfolio composition (between debt and real asset ownership). The direct grant approach via the investment tax credit, by contrast, leads to an increase, relative to the social return on investment, in the rates of return received by savers, but does not bring about their convergence. Provided the basis for depreciation of assets purchased is reduced by the amount of the credit (and provided the original depreciation rates are accurate), this approach also maintains neutrality with respect to portfolio composition. On the other hand, designing the credit to take correct account for differences in asset durability is relatively difficult. Furthermore, the direct grant approach does not share with the consumption tax approach to savings and investment incentives the tendency to displace imperfect income measurement rules as the amount of incentive is increased. In particular, it does not to the same degree reduce the sensitivity of the tax system to the rate of inflation. 
A point that has been emphasized here is the interaction among the consumption tax incentives. In particular, it has been stressed that applying consumption tax incentives to real investment without implementing a corresponding exclusion of interest from tax (and corresponding reduction in interest deductibility) tends to drive real assets into the hands of the highest bracket taxpayers and to negate the potential of the consumption tax approach to bring about convergence of the yields on saving. What has not, to my knowledge, been recognized before is that there is an exact and relatively simple degree of interest inclusion appropriate for each level of write-off of real investment, a fact that would ease a gradual phasing in of a consumption-type base should this be the objective of policy.

Inflation upsets the measurement of the yield of both real and financial assets. S-I incentives are commonly viewed as instruments to offset these measurement problems. However none of them addresses the problem of correcting interest income. As a result it is difficult to reach clear conclusions about their relative properties, because it is difficult to model equilibrium in a graduated tax rate system. Without any correction for tax purposes, a change in the nominal interest rate of $1 /(1-m)$ points per point of inflation is necessary to maintain the after-tax yield of a lender (or after tax cost of a borrower) with marginal tax rate $m$. Thus an interest rate change that just offsets inflation for one taxpayer will be too large or too small for most others. Just where the change settles has a bearing on the predicted effect of measures, such as accelerated depreciation and the ITC, affecting the taxation of real assets. Theory predicts a concentration of real investment in the hands of 
relatively high bracket investors and relatively large changes in interest rates with inflation. To offset the resulting impact on the efficiency and quantity of real investment, accelerated depreciation or the ITC offer possible alternatives to indexing depreciation, but they do not correct the portfolio distortions. Furthermore, observed variation in interest rates does not seem large enough to be consistent with this view. Fully convincing analysis of the alternatives to indexing may have to await the sorting out of this puzzle. 


\section{References}

Aaron, Henry J., 1976, ed., Inflation and the Income Tax. Washington: The Brookings Institution.

Auerbach, Alan J., 1979a, "Inflation and the Choice of Asset Life," Journal of Political Economy, June, 89, pp. 621-38.

Auerbach, Alan J., 1979b, "The Optimal Taxation of Heterogeneous Capital," The Quarterly Journal of Economics, November, 93(4), pp. 589-612.

Auerbach, Alan, J., 1980, "Inflation and the Tax Treatment of Firm Behavior," NBER Working Paper No. 547. September, Cambridge, MA: National Bureau of Economic Research.

Auerbach, Alan J., and Jorgenson, Dale, 1980, "Inflation-Proof Depreciation of Assets," Harvard Business Review, September-October, pp. •

Auerbach, Alan J., 1981, "A Note on the Efficient Design of Investment Incentives," The Economic Journal, March, 91(361), forthcoming.

Boskin, Michael J., 1978, "Taxation, Saving, and the Rate of interest," Journal of Political Economy, April, 86(2, Part 2), pp. S3-S28.

Bradford, David F., 1979, "The Case for a Personal Consumption Tax," in Joseph A. Pechman, ed., What Should be Taxed, Income or Expenditure? Washington: The Brookings Institution, pp. 75-113. 
Bradford, David F., 1980a, "The Economics of Tax Policy Toward Savings," in George M. von Furstenberg, ed., The Government and Capital Formation. Cambridge, MA: Ballinger, pp. 11-71.

Bradford, David F., 1980b, "Tax Neutrality and the Investment Tax Credit," in Henry J. Aaron and Michael J. Boskin, eds., The Economics of Taxation. Washington: The Brookings Institution, pp. 281-298.

Bradford, David F. and Toder, Eric, 1976, "Consumption vs. Income Base Taxes: The Argument on Grounds of Equity and Simplicity, Proceedings of the National Tax Association, pp. 25-31.

Eisner, Robert, 1977, "Capital Shortage: Myth and Reality," American Economic Review, February, 67(1), pp. 110-15.

Fabricant, Solomon, 1978, "Accounting for Business Income Under Inflation:

Current Issues and Views in the United States," The Review of Income and Wealth, March, 24(1), pp. 1-24.

Feldstein, Martin S., 1976, "Inflation, Income Taxes and the Rate of Interest," American Economic Review, December, 66 (4), pp. 809-820.

Feldstein, Martin S., 1977a, "Does the United States Save Too Little?" American Economic Review, February, 67(1), pp. 116-121.

Feldstein, Martin S., 1977b, "National Saving in the United States," in Eli Shapiro and William L. White, eds., Capital for Productivity and Jobs. Englewood Cliffs, N.J.: Prentice-Hall. 
Feldstein, Martin S., 1980, "Inflation, Tax Rules and Investment: Some Econometric Evidence," NBER Working Paper 577. October, Cambridge MA: National Bureau of Economic Research.

Feldstein, Martin S., 1981, "Adjusting Depreciation in an Inflationary Economy," National Tax Journal, March, $34(1)$.

Feldstein, Martin S., and Summers, Lawrence, 1978, "Inflation, Tax Rules, and the Longer Term Interest Rate," Brookings Papers on Economic Activity, (1), pp. 61-109.

Gordon, Roger H., 1980, "Inflation, Taxation, and Corporate Behavior," NBER Working Paper 588. December, Cambridge, MA: National Bureau of Economic Research.

Gordon, Roger J., and Malkiel, Burton G., 1980, "Taxation and Corporate Finance," NBER Working Paper 576. November, Cambridge, MA: National Bureau of Economic Research.

Hall, Robert and Jorgenson, Dale, 1967, "Tax Policy and Investment Behavior," American Economic Review, June, 57(3), pp. 391-414.

Harberger, Arnold C., 1980, "Tax Neutrality in Investment Incentives," in Henry J. Aaron and Michael J. Boskin, eds., The Economics of Taxation. Washington: The Brookings Institution, pp. 299-316. Hendershott, Patric H., and Hu, Sheng-Cheng, 1980, "The Relative Impact of Various Proposals to Stimulate Business Incentives," in George M. von Furstenberg, ed., The Government and Capital Formation. Cambridge, MA: Ballinger, pp. 321-336. 
Institute for Fiscal Studies, 1978, The Structure and Reform of Direct Taxation, Report of a Committee Chaired by Professor J. E. Meade. Iondon: George Allen and Unwin.

Jorgenson, Dale W., 1963, "Capital Theory and Investment Behavior," American Economic Review, May, 233(2), pp. 247-59.

King, Mervyn, 1980, "Savings and Taxation," NBER Working Paper 428, January. Cambridge, MA: National Bureau of Economic Research.

Malkiel, Burton G., 1979, "The Capital Formation Problem in the United States," Journal of Finance, May, 34(2), pp. 291-306.

Pechman, Joseph, 1980, "Tax Policies for the 1980's," Tax Notes, December $22,11(25), \mathrm{pp} \cdot 1195-1208$.

Samuelson, Paul A., 1964, "Tax Deductibility of Economic Depreciation to Insure Invariant Valuations," Journal of Political Economy, December, 72, pp. 604-606.

Shoven, John B. and Bulow, Jeremey I., 1975, "Inflation Accounting and Nonfinancial Corporate Profits: Physical Assets," Brookings Papers on Economic Activity, 3 , pp. 557-611.

Shoven, John B. and Bulow, Jeremy I., 1976, "Inflation Accounting and Nonfinancial Corporate Profits: Financial Assets and Liabilities," Brookings Papers on Economic Activity, 1 , pp. 15-57.

Steuerle, Eugene, 1980, "Is Income from Capital Subject to Individual Income Taxation?" OTA Paper 42. October, Washington: U.S. Treasury Department. 
Stiglitz, Joseph E., 1980, "On the Almost Neutrality of Inflation: Notes on Taxation and The Welfare Costs of Inflation," NBER Working Paper No. 499, July. Cambridge, MA: National Bureau of Economic Research. 